\title{
POPULISM IN WESTERN DEMOCRACIES: A VIEW FROM FRANCE
}

\author{
Bernard BOËNE, PhD \\ emeritus professor of sociology and chancellor of the Geneva School of Governance. \\ Email: chancellor@genevasg.com
}

\begin{abstract}
Drawing upon the extensive literature on populism that has accumulated since the 1960 s, this article first tries to characterize contemporary Western populist movements. Having identified "civic" nuances among populist currents of the Left as well as of the Right, and in between them a moderate populist vote expressing disenchantment with government parties, it hypothesizes (on the basis of secondary analysis of existing studies) that the centre of gravity of the populist nebula in the West resides in a reference to the demos, rather than ethnos or plebs, and that the balance of forces within the populist support base is in its favour. It goes on to probe the causes of growing citizen alienation - the main source of populism. It suggests (based on fifteen unstructured interviews) that while the social aspect - the destabilization of the lower/middle classes induced by the neo-liberal order - is important, it does not exhaust the issue. Systems of representative democracy, put in place over two centuries when the masses were uneducated, are not aging well now that average education have considerably increased and majorities want to make themselves heard. Should that demand be ignored, the problem raised would become structural - and more acute: institutional reform in the direction of redefining the relationships between elites and grassroots, majority and minorities, is thus in order - the sooner the better.
\end{abstract}

Keywords: Populism, Western democracies, neo-liberal order, citizenship, general will.

\section{Introduction}

The ambition to define and fathom populism has generated a considerable, steadily increasing literature since at least the 1960 s - long before the powerful wave that is stirring up many States today and has placed populist leaders in power in some others. Yet to say the least, despite some analytical brainwaves here and there, the conceptual fog that has long prevailed on the subject is not entirely dispelled. The reasons for this are that the perimeter of phenomena that can be classified under the "populist" label is uncertain at best, and that within this perimeter their manifestations are obviously very diverse. Such diversity, which partly stems from their sensitivity to geographic and historical contexts, deprives us of the possibility to treat the variant forms of populism in a way that encompasses them all: attempts at broad generalization seem doomed to fail. The difficulty involved in providing a general definition of populism was recognized over fifty years ago. A conference held on this topic in 1967 at the London School of Economics (which brought together such distinguished minds as Isaiah Berlin, Ernest Gellner, 
Richard Hofstadter, Kenneth Minogue, Alain Touraine, or Franco Venturi) came to the conclusion that no simple answer could be given to the question: "[E]veryone agreed that the subject was too vast not merely to be contained in one 'definition', but to be exhausted in one discussion". (Berlin et al. 1968). ${ }^{1}$

A more modest starting point is to outline the problem and its settings in ideal-typical fashion by specifying the conditions that commonly govern the emergence and development of populist, i.e. anti-elite, protest movements. For that purpose, four contextual criteria deserve attention. The first is that they are inseparable from democratic or at least republican environments: without large numbers of disgruntled citizens who feel dispossessed of one or more of their legitimate attributes, there is no populism - only protests or revolts on the part of subjects, serfs or slaves; the second is that they emerge in contexts of prolonged anomie : without malfunctioning institutions, there is no populism either, since it would then be deprived of immediate grounds for mobilizing, of wider support, and political prospects ; thirdly, populist movements are apt to arise either from below (in which case they direct their anger at ruling elites, and tend to be led by political outsiders) or from above (as when mainstream leaders in office seek to secure their grip on power and to that end rely on popular animus to target social or economic elites opposing their policies at home, or much-maligned external power centres placing constraints on their rule); last, due to the radical solutions they frequently have in mind to remedy institutional malfunctions, such movements may harm democratic or republican principles by paving the way for illiberal options of which they often (though not always) are the bearers.

There is unfortunately no way the analyst can go much further without delving into what is common to specific categories of cases provided by the various periods and places in which populisms have been observed. ${ }^{2}$ If that is so, a choice of particular focus has to be made: the scope of this article will be restricted to contemporary Western democracies.

Two justifications readily come to mind for that decision. If the issue bears upon the relations between populism and democracy, it is only prudent to reserve regions or ages in which the democratic reference is anachronistic, uncertain or still fairly new for special analytical

\footnotetext{
1 The difficulty involved in providing a general definition of populism was recognized over fifty years ago. A conference held on this topic in 1967 at the London School of Economics (which brought together such distinguished minds as Isaiah Berlin, Ernest Gellner, Richard Hofstadter, Kenneth Minogue, Alain Touraine, or Franco Venturi) came to the conclusion that no simple answer could be given to the question: "[E]veryone agreed that the subject was too vast not merely to be contained in one 'definition', but to be exhausted in one discussion".

2 From ancient Greece and its "demagogues" and the ancient Rome of the Gracchi and Clodius all the way to the populist movements and leaders of today, and in between : the United States of the 1830s and 1890s, Boulangism in early Third Republic days, then the shopkeepers' and craftsmen's anti-tax movements of the 1950s and 60s in France, those which brought Getúlio Vargas and Juan Perón to power in Brazil and Argentina between the 1930s and 1950s, the Arab world's socialist populisms of the post-war era, the Canadian Social Credit movement of the 1960-1980 period, the farmers' movements which arose off and on in Italy, France, the Netherlands, Germany and elsewhere, and many others besides. However, the oft-quoted Russian narodniki movement of the 19th century's latter half has no place in that list : as Alain Besançon noted, it is an idealism that, because it failed to arouse the peasants it wished to emancipate, is better categorized as an intellectual than as a social and political movement.
} 
treatments fully doing justice to their specifics ${ }^{3}$ - a task best left to other, more competent authors. A contrario, because populism has forcefully emerged recently where it was least expected: in the West, where democracy originated and is most firmly rooted, it is there that study and interpretation of that phenomenon especially recommend themselves.

Unlike its counterparts in most other regions, the contemporary populist wave on both sides of the North Atlantic has sprung up from below, either induced by new political forces and led by mavericks, or from the pressure applied on hitherto moderate parties by their support bases to radicalize themselves on one or several issues (notably, immigration and the social consequences of the post-2008 financial crisis). It raises several interrelated questions. The first relates to the causes or reasons for its simultaneous success in a large number of countries. The second concerns the peculiar populist style and the attraction it exerts today, which must be accounted for. The third examines whether it represents, as we often hear, a threat to democracy, especially at a time when representative systems are facing an all-too obvious crisis. Underlying the other three, the last can be stated as follows: is it possible to go beyond an insistent parallel with the 1930 s and a facile explanation in terms of irrationality and hatred as a response to the multiform malaise that has set in?

\section{The ingredients of populism: theoretical and empirical overview}

From the literature that has accumulated since the 1960 s some lessons can be drawn, which will be summarized below in fifteen points. It appears from the outset that populism is not an ideology sui generis: it is compatible in that regard with strongly contrasted options (i). Indeed, over and beyond widely shared detestations ${ }^{4}$ (free trade and globalization, big business, banks and the financialisation of the economy, multinational firms, the European Union, public and third-sector international organizations, the media, the arrogance or lack of proximity to citizens of elected officials and leaders above a certain level), one can easily detect a conservative or

\footnotetext{
3 The (contemporary) regions alluded to include : (1) Central and Eastern Europe, where democratic experience (the former (zechoslovakia excepted) does not exceed the last three decades, and whose long history must also be taken into account : the Ottoman threat or occupation up to the end of the 17th century (which may explain its frontal opposition to multiculturalism, explicitly targeting Islam), and the still vivid resentment of the treaties that ended World War I, and deprived some countries, primarily Hungary, of vast territories (which may account for the resurgence of nationalism) ; (2) Latin America, repeatedly subjected to military regimes in the past, is experiencing (with a few exceptions: Argentina and Chile after the end of military dictatorships) rates of political violence and social inequality that are far removed from classic standards of democracy as a regime and society; (3) Asia : India in the last decades (an interesting case, given its strong democratic institutions) and to the extent that they are democracies, the Philippines, Malaysia, and Thailand. (4) Africa, where it takes the form of identity nationalism seen as an extension of anticolonial struggles. Of note is that the diversity of cases is great even within single regions. In Latin America, those of Venezuela, Brazil and some Andean countries are very different. In Europe, the populist wave emerged from below in some places (on the left in the south, due to the 2008 financial crisis, on the right in the west and north, induced by the recent migration crisis), but from above elsewhere: in Eastern Europe, it was government parties that turned to populism.

4 There is a common core that cuts across the diverse varieties of populism, reflected in the votes of their MPs : in the Dutch Parliament, for instance, between 2004 and 2010, left-wing (SP) and right-wing (Geert Wilders' PVV) populist deputies voted the same way in $44 \%$ of cases. Cf. Otjes \& Louwerse (2015).
} 
reactionary pole (marked by an opposition to multiculturalism in all its forms) and a progressive one (itself divided according to whether the struggle aims first at inequality or discrimination) (Otjes and Louwerse, 2015). However, a blurred or confusing picture emerges when the movements or parties involved combine in practice (or without warning alternate between) seemingly contradictory options with regard to this left/right divide (Inglehart and Norris 2016). ${ }^{5}$

The only ideal, politically indeterminate, ingredients that populism exalts are (ii) the general will, easily translated, in a time of now unhappy globalization, into a reaffirmation of political, economic, social and cultural sovereignty, and in a rejection of the constraints that come with international multilateralism; and (iii) a strong belief (reminiscent of Orwell's - in no way populist - common decency) in the virtues of the people, defined as a homogeneous entity, on the Left because it is "inclusive", on the Right because it is (or should be) "monocultural". There follows (iv) a Manichean opposition between the "people" and its "enemies": all those who, holding the high ground, filter the expression of the general will and derail it to serve their collective interests or offbeat worldview. Such mistrust of elites and intermediate bodies (v) derives from an often vehement dissatisfaction with the status quo - from a revisionism (vi) directed, or so it seems, at the institutions themselves ${ }^{6}$ as much as at the deleterious way in which they are being operated by those entrenched within them, held responsible for the current misery because they have cut themselves off from "ordinary people" whose aspirations they no longer understand, or despise.? Resulting therefrom is (vii) a nostalgia for a golden age when democratic citizens, in full possession of their rights and aware of their duties, were not treated as minors by a "framed democracy".

Among other hard-to-deny surface features that many observers pinpoint are the facts that (viii) populist movements are more often than not embodied in charismatic leaders who give their expression a personal, often decisive, turn - although they surf waves created by the context much more than they initiate them in order to storm into power, or to exist politically; (ix)

5 Donald Trump has made such practice a habit : in the tradition of George C. Wallace, he combines "leftist" policies, tending to protect workers and farmers through protectionism, preserve certain benefits (social security, Medicare, etc.), and stimulate economic activity through spending on infrastructure, with hard-right orientations when it comes to immigration, liberalization of societal norms, and external multilateralism. The confusion created, even in supposedly informed circles, by this unusual mixture of policies or orientations is real: it may explain, for example, why in Inglehart \& Norris (2016) movements or parties commonly catalogued as right- or extreme right-wing (Fidesz and Jobbik in Hungary, PiS in Poland, Golden Dawn in Greece) are classified as "left-wing populists".

6 Populist discourses often include a dimension that is subversive of the existing order, but also a redemptive one, promising the establishment of a better democratic order: a more direct link between the people and government notably by encouraging the consultation of the former on the main options open to it. This underlines the crisis of representative democracy experienced by most Western nations, and the populist disdain for the procedural forms of democratic processes.

7 This results in a "throw-the-rascals-out" posture ("dégagisme"), and an explicit desire to de-professionalize politics. In France, the "yellow vests" movement of 2018 was strongly reluctant to appoint spokespersons or representatives (despite the insistence of the media and government, in need of contacts for "dialogue" purposes). The populists' mistrust of elites even applies to their own leaders when, whether or not associated with doctrinal fights, people's quarrels come to light at the top, usually on the Left rather than on the Right. This is what we have seen successively, for instance, in the Scottish Socialist Party (2006), Spain's PODEMOS (2016) or La France Insoumise (2018). 
far from identifying with easily recognizable groups or social backgrounds, their audience presents a "catch-all" character that transcends traditional divides; and $(x)$ their success does not necessarily seem linked to a major economic crisis (although it can serve them where it is), since they are seen to flourish in contexts (United States, Germany, Switzerland, Sweden, and many other countries) where no despair of this type is observed today (see Camus 2018). ${ }^{8}$ Often alleged but more ambiguous are their anti-pluralistic inclinations (xi). Such are certainly reflected in the populist mistrust of countervailing powers - not least the media - which have supposedly turned into objective accomplices of the "system" and the "people above", no longer adequately relay demands "from below", and are seen as part and parcel of an "establishment" that is the source of almost all ills. But populism conceives of itself as a response to the absence of true pluralism - as an alternative to the indistinguishable policies implemented by rulers of both right and left as a result of strong external constraints, electoral strategies aimed at conquest of the political centre, and a single elite mindset that it no longer finds bearable. If populists aspire to a certain unanimity, it is because they know that is the price to pay to preserve unity within their motley ranks - a unity cemented by revisionism as long as fighting the "system" is the order of the day, but which would be jeopardized if positive options had to be defined. (This may also explain why they seem less successful when they inhabit the corridors of power than when they are agitating at its doors). If, then, populism does not present itself straightforwardly as a positive and unequivocal ideology, as a movement with a clearly defined support base, or as a strategy of access to power, what is it? The best way to define it is probably to see it first and foremost, as does a large part of the literature, as a political style (xii). More precisely, as a rhetoric and posture whose general tone is easily recognizable: depending on location, it marks the emergence or the return of political dissensus, which it shapes through and through. Its trademark, verbal bluntness, borrows from both a right-wing polemic tradition ${ }^{9}$ and caustic working-class banter, and is easily distinguished by its rejection of decorum, propriety, or even politeness. To this must be added the liberties it takes with established truths - its notorious recourse to "alternative facts" -, its sometimes ad hominem verbal attacks, and the confidence with which it is apt to affirm or do today the opposite of the day before. The histrionics of its leaders seem to be inherent in it, as is the delectation its often "politically incorrect" language provides. An interesting point is that populist leaders do not shelve this more or less markedly demagogic style once in high State office, but maintain it as a communication strategy - a means for them to safeguard the unity of their electoral support base despite the ambiguity,

\footnotetext{
8 This limits the scope of the parallel often invoked with the 1930s, already weakened by a major difference: we do not live today in the shadow of revanchist militarism and a possible major war between big neighbours. Today's stress on sovereignty is devoid of aggressive nationalism in international affairs, and the present forms of populism in the West can hardly be equated with the fascism of that fateful decade.

9 However, it should be noted that the language used remains far less abusive than in the 1930s on the Right. In particular, the virulent anti-Semitism of those years finds no parallel in the recent period. The only trace of resentment against Jews resides in cases of ambiguous undertones in political discourse in relation to the perceived failures of global financial capitalism. But that is not specifically tied to populism or to the Right (as witnessed by the intimations for which British Labour Party leader Jeremy Corbyn recently drew fire).
} 
or the zigzags, of the policies they conduct - and to continue distinguishing themselves from the hated elites who preceded them in power (xiii). Another proven way is, through the transgression of forms, to cultivate the charisma that befits those who want to embody the popular will, and which induces in them, when in power, a "Platonic" manner of exercising it: as long as they are assured of the support (measured by polls) of their electorate, populist leaders can free themselves from legal forms or norms, even brave judicial risks, and leave scrupulous respect of legality to Statespersons of lesser status.

Last but not by any means least, the populist style is greatly favoured in terms of audience by media hungry for controversy (Rooduijn 2018) ${ }^{10}$ and even more so by the massive influence of the information and communication technologies (Facebook, Twitter, and the like) available today, which are the extremely reactive ("viral") vectors of expression or mobilization of the masses' spontaneity, transgressive affect and inclinations (xiv). The effectiveness of this style its postures, slogans and simplisms, multiplied by the wide, instant diffusion that these social networks ensure - is such that it has become contagious and that it now affects, concerned as they are to speak the language of the people, leaders of mainstream parties. So that (xv) today's populism is as much a matter of degree as of kind (March 2017). ${ }^{11}$

\section{Motivations and varieties of populism}

What are the motivations of the supposedly central "civic" variety of populism? The distrust of any representative system and insistence on the general will are of course reminiscent of Rousseau (which may explain why these traits seem more marked in France than elsewhere). We know that in his eyes the transmutation of majority feeling into the general will to which all citizens are supposed to bend through the law is the keystone of democracy. So strong before the introduction in 1958 of the constitutional review principle (and its affirmation in practice after 1971), the French "legicentric" tradition finds its roots there. But, obviously, it now arouses nostalgia, and echoes abroad. We also know that the majority principle's justification, as Georg Simmel (1907) reminded us, is somewhat tenuous: "'That an opinion expresses exactly the sense of the supra-individual unity of the whole for the sole reason that those who carry it are in greater numbers than those of another opinion is indeed an indemonstrable dogma, and even so weakly founded a priori that if we do not resort to a more or less mystical relation between this unit and the majority, it does not really stand up, or rests on a rather pitiful principle: after all, something needs to be done, and if it really is not permissible to assume that the majority as such knows what to do, then a fortiori, there is no reason to think that the minority is in a

10 Populism generates echoes - to an extent that is more than proportional to the news it creates - in a print media in desperate search of compelling stories because it is faced with declining subscriptions and advertising revenues, and strong competition from news websites and social media. This is what Matthijs Rooduijn notes in The Guardian dated November 20, 2018: while this "quality" British newspaper published some 300 articles containing the terms "populism" or "populist" in 1998, this figure rose to 1,000 in 2015, and doubled yet again in 2016.

11 Hence the use for empirical research purposes of populism scales that measure the degree of populism in party political expression, especially through electoral manifestos. While most such attempts rely on synthetic scores, others break populism down into distinct dimensions to bring out nuances that would otherwise be out of reach. 
position to know any better". Moreover, this principle has been undermined for some time by two circumstances: electoral results are often tight, and the magnitude of abstentions as well as blank or void votes is such that the winner (or the victorious option in a referendum) only garners a minority of registered voters. It is not therefore on electoral majorities that the "centrist" populist demand for a revitalization of citizenship can be based, but on the supposedly central majority core of those who accept the duty of citizens: to pass their own (material, but also expressive) interests after the general interest, a condition on which the pursuit of the common good is premised. However, for half a century, social evolution has been in the direction of individual emancipation at the expense of citizen allegiances, threatening the production of the common good, and turning political majorities into coalitions of minorities on which rest the electoral strategies of government parties.

These minorities are no longer just the mark of political and socio-economic disagreements: driven by the growing need for expressiveness, they are cultural and thirst for recognition of their identities. They are defined by ways of life or moral causes rather than by material interests, and they have multiplied: feminists, gays and lesbians, ethno-racial groups differentiated according to their origin, transgender people, vegans, zealots of the animal cause - the list is hardly exhausted. Over the last half-century, they have made themselves heard, on the initiative of often virulent activists or moral entrepreneurs, by noisy transgressions of dominant norms in order to have their status as victims of discrimination or the moral legitimacy of their cause fully recognized, to lend credence to the "normality" of their practices, impose their vocabulary and language prohibitions, and finally to have them set, under pressure, in legislative stone. The mainstream of Western societies long left them unchallenged, convinced that emancipation and its attendant hedonism, resulting in a new primacy of the individual, were a good thing, and that in the atmosphere thus created certain social norms and old stigmas were outdated. However, it began to stiffen when such change ceased to be entirely painless: when, for ever larger segments of societies, it became a source of multiple constraints in everyday life, both public and private. It baulked when insistent "politically correct" norms made their appearance, suggesting that outside of the liberal-libertarian path that was being traced for it, there could be no salvation. It stiffened even more when the media turned into self-appointed guardians of this doxa (now seen as a banner of moral virtue) ${ }^{12}$ and joined the activists in denouncing all reservations as the mark of mentally retarded hatemongers, subject to various "phobias" that the new laws now allowed to prosecute. This has led to situations where groups representing $4 \%$ or even

12 This is the case in the US, where public confidence in the media has gone through a long-term decline: from $72 \%$ in 1976 to $50-55 \%$ between 1997 and 2005, before falling to just over $40 \%$ on average over the next ten years; it stood at 32\% in 2016 (cf. https://news.gallup.com/poll/1663/media-use-evaluation.aspx). This two-step loss of trust coincided with the emergence of "culture wars" (1985-1995), then with that of "politically correctness". Interestingly, over the 1997-2017 period, supporters of the Democratic Party were more satisfied with the media (in proportions of around $60 \%$ on average) than declared Independents and Republicans (whose trust went down respectively from 50 to $35 \%$ and 45 to $25 \%$ between the first and second half of that period), which signals a perception by more than half the adult population of a leftist bias in the media treatment of the news. Such synthetic statistics unfortunately appear to be unavailable for Western Europe 


\section{Security}

$0.5 \%$ of the adult population can force the remaining 96 or $99.5 \%$ to adjust to new standards, to monitor their language at all times (or face the risk of inadvertently offending someone), revise their grammar and spelling, and even redefine their identities according to categories imposed by one or more minorities. Thus, for example, some countries (Germany, Canada, India, plus a number of states in America) have now added a third genre to the traditional division between men and women, for the benefit of those who identify with neither of these binary categories, making it necessary in the process to review the whole edifice of civil law. Still this may only be the beginning: $:^{13}$ the vogue among activists of the concept of "intersectionality" (the accumulation by certain groups of minority attributes seen as stigmatized or a source of victimization) suggests that the emergence of micro-minorities, each with its agenda of constraints to impose on the rest of society, is in the offing. Moreover, as new immigrant arrivals tend not to assimilate, and second- or third generation Muslim nationals (for whom religion is a marker of their rejection of a society that discriminates against them) often return to their cultural roots, difficult though essential questions are raised about possible cases of conflicting fundamental norms (civil law vs. sharia), security (due to a halo effect which in perceptions makes these groups a potential breeding ground for home-grown Islamist terrorism), liberties (forced marriages, attitudes towards women, homosexuals, apostates, etc.), and identity (which up till then majorities scarcely claimed, but now seek a groping definition of in order to counter its dilution). Despite the promise of immigration as a source of labour in countries where unemployment is unheard of (Germany, Scandinavia, Switzerland, the US and others), a non-negligible part of the population sees it as either a burden, a threat, or the introduction of an alien culture, and it has given rise to the emergence of parties that specifically target it - with a fair degree of electoral success. Other segments, seemingly more numerous, accept it as an irreversible fact, but nonetheless demand of immigrants tangible signs of integration and, in the face of a sudden increase in migratory pressure, a stricter control of future inflows. Annoyance is palpable when activists of (self-mandated) associations or NGOs dress the issue in ethical garb (in terms of a duty of compassion, humanity, hospitality, etc., as if the sermon on the mountain could serve as a foundation for policy), and denounce as morally despicable those who question their options. And when the citizen turns to the past to ask how we got there, he or she does not recall ever having been consulted on an issue that, like this one, was apt to alter the face of society: one is referred back to the denial of democracy populists make so much of. ${ }^{14}$

A fearful mechanism is set in train when political elites, renouncing citizen universalism, come to believe that the promotion of differences and "diversity" is the only way to manage the consequences of their predecessors' imprudence, and when the entertainment industry decides

13 Beyond this new three-part division, the literature on gender suggests that when combining (present, indistinct or absent) genital attributes with sexual orientations and practices, the total number of possible genders reaches several tens ( 35 or 63 , depending on authors). Societies are thus invited to a mental revolution demanding that they forgo familiar social landscapes.

14 In France, the decision to ease family reunion for immigrant workers, a move that powerfully transformed French demographics in a generation and a half, was made in 1976 by executive order, and passed largely unnoticed at the time. 
to give them a hand. This is what happens, for example, when the French viewer finds that in almost all TV crime series, the investigation is conducted by a woman - against all probability: women make up only a quarter of the workforce of ranking investigative branch police officers - or that, if male, the person in a position of authority very often comes from "diversity" backgrounds unless he is old, ridiculous, or pathetic. The average man on the other side of the TV screen eventually comes to understand that the director of the series sees him as a being steeped in prejudice that society needs to fight (which he will deem unpleasant if precisely he had never thought of denying anyone a rewarding merit-based career in the police). Perceiving that he is being assimilated to the undifferentiated mass of "dominant white males" suspected of sexism or racism, he may see good reason to question the insistence of an implicit message that describes him as a figure of the past. He may in turn - especially if he feels dominated rather than dominant - denounce ideological collusion among elites of all kinds who never miss an opportunity to deliver that message and take on the best role at his expense. In the worst case, he will mentally identify with the target group, and will be tempted by paranoia: a perfect case of self-fulfilling prophecy. What these illustrations suggest is that for a very large part of the population, the subjective cost of a society that grants all the claims of cultural minority groups may be much higher than meets the eye. The long-held frustration that results from such a predicament goes far to explain the populist style's appeal, and the popularity of leaders when they crudely give vent to it verbally - it brings many people psychological relief. This frustrated subjective dimension is probably one of the most powerful driving forces of populism. It derives much of its strength from the imbalance that now affects the relations between majority and minorities. Such an imbalance invites us to reconsider some classical conceptions: if, on the basis of what he had seen in Andrew Jackson's (populist) America, Tocqueville had been able to point to majoritarian tyranny as one of the dangers lurking for democracy (John Stuart Mill later joined him in this belief), many are now reversing the proposal and denounce a tyranny of minorities. However, exasperated subjectivities hardly exhaust the issue. Indeed, the present configuration of relationships between large and small numbers is not without raising yet other fundamental sociopolitical questions, as shown by the example of the United States (where it has prevailed for a longer period than in Europe, and where some trends are more firmly delineated). Cultural minorities that have become expressive and clamour for the free manifestation of their differences in public spaces (instead of reserving them, as in the past, for their private spheres) are subject to the temptation to isolate themselves by cultivating their identities apart from the rest of society. Their demands of the outside are such that they make intercourse with them a rough experience, and they end up limiting any interaction and dialogue to their members (a possibility afforded them by social networks). When on the defensive, they are tempted to protect themselves from "micro-aggressions" in "safe places" from which any presence other than that of their members is banned. ${ }^{15}$ Going on the offensive, they attack any cultural, including

15 Safe places were initially an initiative to protect vulnerable groups (e.g., disabled or autistic people). This practice was soon adopted by groups that are not: race or feminist groups have recently taken to organizing meetings closed to Whites or men. This practice, now common in some circles in the United States, is beginning to creep into Europe. 
artistic, language or portrayal at variance with their specific values, 53 or any content borrowed from types of expression they consider strictly their own. In doing so, they turn their identities into essentialist sanctuaries while at the same time criticizing the mainstream for tentatively defining what characterizes it. Worse, they institute a regime of self-censorship, and censorship tout court for writers or artists now vulnerable to the wrath of the judicial system (Pierrat 2018).

The image of society looming on the horizon if this logic's momentum were given free rein is that of populations divided into silos, where only those who feel they belong to the same minority are in contact with one another, and protect themselves from whatever looks alien to it. This raises the question of the possibility of generating enough common ground between social groups to form viable societies, or even of peaceful coexistence among them. This vision is sufficiently problematic for even authors who place discriminated groups at the centre of the plebeian "people" they wish to see emerge, like Ernesto Laclau (2000) or Benjamin Arditi (2007), to worry about the perspective it opens up : a system of voluntary apartheid as the culmination of an integral differentialism whose aporia they emphasize.

Forty years ago, Serge Moscovici saw the coming of an "age of minorities". Four decades later, populist impulses sound like a call to democratic order: if majorities cannot do as they please all of the time, they have at least the right not to allow Gulliver to be bound to the ground by Lilliputians. Forgotten, their opinions ignored ${ }^{16}$ grassroots citizens are ranked (as Jacques Rancière would say, though in a very different sense) among those who do not count. They now invite their elites to come down to earth, and reverse course.

\section{How to assess these movements' historical significance?}

How, in light of the "civic" hypothesis advanced (and the factors enumerated) above, can one account for their emergence and simultaneous success throughout the West? At the risk of offering but a very schematic interpretation, answers to these questions can be formulated as follows. At the beginning of the process is the accelerated individualization of social relations. The thing is relatively new: even if the Individual was from the beginning on the scores that Modernity plays, it only made its full effects felt during the last half-century. The mechanics of individualization are driven by various engines that were clearly seen in statu nascendi by classical sociologists. ${ }^{17}$ All relate to long-term social equalization processes and to technological

16 This applies in particular to European policy matters: public opinions in France and the Netherlands have not forgotten that their governments and the EU ignored their "no" votes in their respective 2005 referendums on the proposed European constitution, nor do Irish voters forget that they were strongly invited to reconsider and vote again in 2002 after their initial rejection of the Nice Treaty.

17 Tocqueville (progress of equality, hence of competition and relative deprivation, at the expense of solidarity), Tarde (logic of dispersion induced by the development of means of communication, which by exempting individuals from physical co-presence erodes their sense of community and transforms them into members of impersonal "publics"), Durkheim (deepening division of labour), Simmel (money as a universal medium that liberates people from dependence on proximate others; the individual at the crossroads of multiple social circles, free to choose among their norms those to which he or she will submit), T.H. Marshall (progress of social rights, which substitute the welfare state for the family or local solidarities of old); Lipset (effects of rising standards of living and education levels on the independence and critical thinking of individuals). 
development (not least the specialization and complex organizational relationships that it induces); to the rise of the monetary economy and of much higher living standards; to the emergence of social rights and the security they afford with regard to the hazards of life ; finally, to higher levels of education; all tend to diversify experiences, to free individuals from dependence on small local (including family) groups and from submission to their norms - in short, they relax social ties, and strengthen personal liberty, free choice and critical mind.

It was not until the consequences (notably on the younger generations from the 1960s onwards) of unprecedented economic development levels impacted societies that these engines started to run at full throttle. Michel Forsés application (1987) of the principles of thermodynamics to social processes taught us that in a closed society with a stable workforce, any increase in available resources results in a spontaneous tendency to equalize socio-economic statuses and lifestyles (and that this tends to loosen social bonds). It should be noted that, conversely, the opening of the system's borders generates a resurgence of inequalities within it, which illuminates the effect of globalization almost everywhere since the 1990s. This evolution was eased along by the older generations' memories from the two world wars, and by ideological fatigue in the final stages of the Cold War. Hedonism ensued, which predominantly took the form of narcissistic expressiveness: the free manifestation of one's tastes and life choices - of one's individual "authenticity". In now affluent societies, goods and services are consumed less for the need they satisfy or their practical utility value, than as signs of differentiation or distinction: the rise of "postmaterialism" can also partly be explained in this way. To a certain extent, except for a few still stigmatized groups, social identity is now chosen rather than assigned: reference groups define it as much as membership groups, if not more. Forsé (op.cit., p.140) explains that with "an increase in entropy due to growth (swelling of the middle class, averaging out of lifestyles, etc.), the system had to provide new distinctive criteria, and thus new sources of identification. As a result, today occupational status seems to be no more than a means of social classification among others. As it mitigates the homogenization trend, the diversification of sources of identity leads to a more complex identity mechanism and gives agents leeway that they did not enjoy before. Having to act on different planes to compose their image, they can now opt for strategic behaviour". He adds that associations [N.B. whose number in France rocketed from 20,000 in 1970 to 70,000 in 1990 before fluctuating around this last figure since then] was one of the most commonly used vehicles for implementing these strategies.

To sum up, the last half-century has seen a radical emancipation of the individual, one likely to deliver serious blows to citizen's allegiances. One of the most profound meanings of the movements that broke out in 1968 in France and the United States (with less spectacular but no less real reverberations elsewhere) lay in the rejection by the then younger generation of the notion of citizen duties. This has carried an important consequence for democratic political systems: as emancipated individuals (and the minorities they identify with) feel weak and vulnerable to institutions, organizations and society in general, they tend to fear power in whatever form, and to resist it as much as they can. They challenge it collectively, or rely on the pressure applied by the most militant to erect walls of legal protection around them, guaranteeing new, 
eagerly sought-after rights. From the 1970s on, the term "domination" has assumed increasingly negative connotations - even when domination is in theory legitimate. Intellectuals, in the broadest sense including teachers and journalists, have turned into critics of the dominant order, and thinkers who have gained fame are those who do not shy away from negativism. In such conditions, power and authority become difficult to exercise. Government leaders' position is weakened: after shorter and shorter political honeymoons upon assumption of office, their confidence or popularity ratings regularly fall, most often to vertiginous depths. Their capacity to deliver on their promises and for transforming society is now much lower than it used to be, and after a few decades the discredit they suffer has now extended to the representative system as a whole. If corporate managers (to whom neo-liberalism has given a freer hand) seem better off, it is essentially because of a lower media visibility - but inside companies disputes are rife (and routinely take the form of factory occupations, or even, in France, forcible confinement of executives). Cultural power hardly fares any better, to the point that, for instance, works of contemporary art that are deemed offensive by outsiders have been known to be deliberately deteriorated. Journalists are no longer welcome in many places or circles, and major electronic media anchor people, treated as "public speech oligarchs", arouse barely less distrust than politicians. Experts, especially on sensitive topics, are suspected a priori of bias, complaisance, or conflicts of interest; so are social scientists when their findings are transparently tainted with ideological concerns or manipulation; even "hard" science does not entirely escape such strictures, when reports of false data used in previously acclaimed studies surface in the press, or large public opinion segments worry about possible applications of new discoveries. As for intellectual influence, it seems to have literally vaporized outside of academia. After decades of simplistic ethics of conviction resulting in disasters (as in Libya in 2011), subversion of concepts as well as methods, and promotion of cognitive and cultural relativism (whose legacy is the post-modern mantra- all reality is socially constructed, and the given is "fascist"), it is disarmed today when faced with the "monstrosity" of "alternative facts". No word seems able to carry weight any more: our age is experiencing a twilight of authority (of which contemporary comedians' derisive tone and mockery of just about everything is emblematic). All of this paved the way for populist rhetoric and style, which would not have been otherwise possible. In the face of allround contestation, the wielders of authority and power in a democracy do not directly impose their options any more (except in technical matters, which for this reason they tend to favour as sources of solutions): they seek advice from experts in the media eye, consult or negotiate with the most vocal activists, delegate to independent nonpartisan authorities or committees of ranking academics, and grant concessions, soon turning into new standards, to the agenda of militant associations or cultural minorities, in the name of humane feelings or pacification of controversies in the public domain. To cover themselves, they use law and worthy sentiments as fig leaves they end up abusing. This is what, as early as 1968, a Dutch author (writing about his country, pioneering in its early advent as well as in recent protests against it) named the politics of accommodation (Lijphart 1968). 
Moreover, be it as humane and well-meaning as it may, the concern to promote an "inclusive" society (one that leaves no one by the wayside) is the source of a headlong race to the margins: one that is self-defeating and lost in advance because those who live on the fringes of society more often than not do so for the heck of it, so that systematically trying to integrate them only invites the creation of new marginal lifestyles. And it has an insidious downside : as it is simpler and far less troublesome for those in political office to impose on loyal, law-abiding grass-roots citizens submissively engaged in living their lives, and who until then had relied on their governors to represent and protect them - the large number of natural men that Isaiah Berlin, paraphrasing Diderot, contrasted with the small numbers of artificial men -, the temptation is great to coerce, suspect, manipulate, and punish them if they pretend to resist, all the while adorning this posture with the prestige of morality - that of people who "do honour to mankind". But the grass-roots have now come to suspect that such a posture only poorly hides their elites' intellectual and moral superiority complex, their lack of legitimacy, and their panic fear at the thought of having to repress true deviants. In addition, what with globalization, laborious European compromises, and neo-liberal injunctions, far from being the locus where a societal project is defined and implemented, politics has for three decades boiled down to mere management of constraints, resources, crises, and demands from active minorities. Perhaps to conceal it, those in office have taken refuge in incantatory exaltation of the rule of law, and of new rights giving rise to solemn international declarations. This is what, as early as 1997, philosopher Paul Thibaud had insightfully identified as a deactivation of democracy: "As has become clear since 1989, the problem of contemporary democracies is (...) [that] they have increased and institutionalized the distance between the people and those in office. (...) They have empowered any amount of new intermediate bodies interposing between the will of the people and the management of public affairs. The shift from the sovereignty of the law to that of the constitution, and then to declarations of rights, has increased the power of exegetes, but diminished that of representatives to the point of making suffrage a lazy king. The rule of law (especially when the law is internationalized) is closed to citizens, suspected of liberticidal leanings. European regulations, justified by the necessity of practical compromise, do not refer to any general will nor even to any general interest, and illustrate how the body politic has been set aside. The state of disrepair affecting the Welfare State is the material side of a breach of the citizenship contract, of which the exhaustion of political representation is another facet. (...) The rulers who have taken politics out of the political for short-term gains (have others dictate terms that they themselves dared not propose) are now impotent in the face of a reluctant and withdrawn society". The author adds: "those who ring alarm bells believing this is 1933 all over again do not seem to understand the difference between a rejection of democracy and the effects of its deactivation" (ibid.).

The reaction of the body politic to this state of affairs was at first apathy, in the form of growing abstention, or volatile voting in successive elections; next, those citizens suffering from socio-economic or cultural insecurity started relying on protest votes for extreme or even demonized parties or leaders in order to make themselves heard (a development that outraged 


\section{Security}

the supporters of the dominant doxa, yet did not open any remediation prospect as the likes of J.-M. Le Pen were then unlikely to access power). The latest stage in this unfolding drama is the populist upsurge of the last few years. Viewed through this prism, the emergence of populism signals the end of a master trend which started in the 1960s. The logic of individualization that underlies it is reaching its outer limits. It is now confronted with a new phenomenon: the militancy of majorities who no longer recognize themselves in its ultimate consequences, know they cannot be dispensed with or by-passed if they won't allow it, and are clearly determined to make it known. It is a proxy militancy relying on movements or leaders who have opted out of the existing political consensus, whom they support and for whom they reserve the right to vote if their main, long unmet demand - put an end to the gap between ruling elites, their state of mind and their practices, and the general will of a body politic whose sense of alienation from the system has been steadily growing over time - were to remain stubbornly ignored. The fifteen characteristics which served to describe contemporary Western populism straightforwardly derive therefrom. The demands placed on the political system are heterogeneous and vague, and the agents of populism, like their sympathizers, are most often hard-pressed to state the deeper meaning, to date still latent and hardly audible, of their action or support. Yet it should be noted that this is precisely what makes possible the "logic of equivalence" and the "empty signifiers" that populist movements require if they are to exist at all - and that analysts and commentators hardly do any better. As a philosopher lucidly pointed out in a recent op-ed piece, "populism is a phenomenon of historic proportions, but it seems as though we do not have the proper intellectual categories to think it through" (Guénard 2018).

Because they are more concrete and more urgent, social demands are mentioned first by populist agents and external commentators alike. This article has argued that this is only the visible tip of the phenomenon, often its occasional cause, and that what we are talking about is a restoration of the citizen spirit and of political practices that no longer ignore the opinions of the "people". Observation indeed suggests that of the three possible orientations of populism, the one that best describes its spirit - the "centrist" reference to the demos - is also (except in the case of France's "yellow vests") the most discreet in its expression. This is no doubt why, eclipsed by the more showy and decibel-charged expression of supporters of the "people" as plebs or as ethnos, it tends to escape superficial attention. If such is the case, no purely social remediation will completely extinguish the fire; the "convergence of struggles" hoped for by radical leftists will not happen any time soon, at least not on account of the populists; and the stiff solutions advanced by right-wing populism, more influential than its counterpart on the Left, will probably be mitigated by the balance of forces and the nuances within each camp described earlier. If things are to improve, the institutional reforms to which the "populists of the centre" aspire need to be instituted without too much delay.

\section{Tentative conclusions: Is populism a threat to democracy?}

Is the populism described above a threat to democracy? The only reasoned answer that can be given to such a question is: it depends - here as elsewhere, the future is open. It is highly 


\section{Securitity}

possible that the central core identified - insisting as it often does on its non-partisan ("apolitical", or of both "right and left") character, and on its refusal to be taken over by anyone - may allow extremists to outflank it, an outcome that cannot be excluded due to its porosity and political indeterminacy. There would then be cause for worry - even if populism rises against the system in the name of democracy, not against it, and has so far shown no alarming illiberal inclinations in the West. It is also possible, however, that the populists now in power, or at the source of potentially reckless options (e.g., Brexit), may discredit themselves due to calamitous results of their policies (plummeting purchasing power, mass exodus of nationals, etc.), in which case their example would be unlikely to spread, and anxiety would be laid to rest. But that is not the way things seem to be going in the West: as staggering as they are, Donald Trump's seemingly erratic moves have so far failed to generate any disaster, nor any attack on democratic institutions or freedoms; the same seems true in Italy of Matteo Salvini et al, and there is no indication that Brexit will not take place despite its practical drawbacks. The suspense will probably hold for some time yet. To compound matters, even the most favourable reform scenario is not entirely problem-free. The constitutional issues to be settled indeed promise to be difficult ones. It will be necessary for the new institutional order to avoid incoherence, paralysis and deadlock - all of which Dahrendorf (1974) long ago identified as serious risks whenever citizens take a more direct part in statecraft. There will be an overriding need to ensure that the active intervention of majorities of until then politically passive citizens does not impinge on pluralism and the liberties of minorities or activists, ${ }_{18}^{18}$ even though they will now be deprived of the power to impose systematically on the majority by taking advantage of weak political leaderships. The ruling elites themselves will also have to change their mindsets and practices: they should stop suspecting the "people" a priori, refrain from regarding it as a modern Gulliver that can readily be entangled, manipulated, lectured or indoctrinated, and even think of setting an example through collective behaviour that reflects something other than the desire to maintain their privileges through optimization of their economic, social and symbolic capital.

The task will be all the more arduous as, even if the engines of individualization come to a halt (it seems difficult to go much further in this direction), they will not run in reverse: the need for distinctive identities and expressiveness on the part of individuals, their fear of power and mistrust of others, the dominant consumerist logic, as well as the notion that the real must yield to desire, will not easily vanish from the scene - barring major crises or wars - and readily be replaced by a return to citizen allegiances and concern for the general interest. In a context where representative democracy gives obvious signs of not aging well, the populists, with all their faults and outrages, nevertheless point to a requirement for such a return. The institutional devices put in place over two centuries, in eras when the masses were still uneducated, are in decided need of repair now that the governed enjoy much higher levels of education on

18 The Tocquevillian view that associations and a vibrant civil society serve to enhance democracy has been dominant since the 1970s. Under its aegis, the political weakness of those in power has resulted in a premium given to the more militant associations, more often than not out of step with the mainstream. A better balance must be struck between freedoms and consensus, conservatism and change. 


\section{Security}

average, and accordingly wish to make themselves heard in between election times. For this reason, remediation requires a redefinition of relations between elites and the "people" on the one hand, the majority and cultural or activist minorities, on the other. It involves a popular right of veto or, more positively, a degree of citizen input into the formulation of policy. Absent such remedies, the problem identified would become structural, have every chance of growing more acute, and come back to haunt democracies, perhaps in a more virulent form - the writing is on the wall. Conversely, if by chance the required institutional reform comes about soon, the contemporary episode will not have been in vain. It will have served to remind us that the "people" is not just a "multitude" or a set of "populations" sharing the same territory: it is also a political subject, which gives meaning to democracy; that the tension inherent in the human condition - each of us is both a "private citizen" and a member of the community (zoon politikon), a specimen (as Simmel, op.cit., again averred) of the "duality between the individual's own life and that of the social totality" - is insurmountable, and "tragic in principle"; lastly, that the individual-is-king philosophy, the main source of the general malaise that has taken hold, was destined to reveal its natural limits sooner or later. Apparently, as the surge of populism bluntly informs us, these limits have now been reached.

In summary, unless the diagnosis offered above is in complete error, as they grapple with populism Western political systems are confronted with a choice: take into account, in the hope of a regenerated democracy, the underlying meaning its civic variety seems to be carrying, or continue sliding down the slippery slope of disenchantment and malaise, with perhaps a leap in the dark at the end of the road. Let us keep our fingers crossed.

\section{References}

1. Arditi Benjamin (2007), Politics on the Edges of Liberalism:Difference, Populism, Revolution, Agitation, Edinburgh, Edinburgh University Press.

2. Berlin Isaiah et alii (1968), "To Define Populism", Government \& Opposition, vol.3, n².

3. Camus Jean-Yves (2018), "Comment expliquer le retour fracassant des populismes?", Les Inrockuptibles, 3 September, available at https://www.lesinrocks.com/2018/09/03/actualite/politique/comment-expliquer-le-retour-fracassant-despopulismes-111120796/

4. Dahrendorf Ralf (1974), "Citizenship and Beyond : The Dynamics of an Idea", Social Research, vol.41, n०\%.

5. Forsé Michel (1987), L'ordre improbable, Paris, P.U.F.

6. Guénard Florent (2018), "L'élection ne peut pas être le seul gage démocratique", Le Monde, July 7.

7. Inglehart Ronald and Pippa Norris (2016), "Trump, Brexit, and the Rise of Populism", Harvard Kennedy School Faculty Research Working Paper, RWP 16-026.

8. Laclau Ernesto (2000), La guerre des identités: grammaire de l'émancipation, Paris, La Découverte

9. Lijphart Arend (1968), The Politics of Accommodation: Pluralism and Democracy in the Netherlands, Berkeley, University of California Press. 
10. March Luke (2017), "Contrary to popular opinion, there is no populist upsurge in Britain", LSE Blog, available at http://blogs.lse.ac.uk/brexit/2017/10/18/contrary-to-popularopinion-there-is-no-populist-upsurge-in-britain/.

11. Otjes Simon \& Tom Louwerse (2015), "Populists in Parliament: Comparing Left-Wing and Right-Wing Populism in the Netherlands", Political Studies, vol.63, n¹ : https:// onlinelibrary.wiley.com/doi/full/10.1111/1467-9248.12089.

12. Pierrat Emmanuel (2018), Nouvelles morales, nouvelles censures, Paris, Gallimard.

13. Rooduijn Matthijs (2018), "Why is populism suddenly all the rage?", 20 November, available at https://www.theguardian.com/world/political-science/2018/nov/20/why-ispopulism-suddenly-so-sexy-the-reasons-are-many

14. Simmel Georg (1907), "Die Überstimmung. Eine soziologische Studie", Vossische Zeitung, $n^{\circ} 91,23$ February.

15. Thibaud Paul (1997), Vingtième Siècle, n56, October-December. 